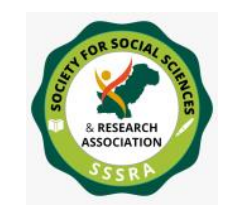

\title{
NEW SILK ROAD: IMPLICATIONS OF ECONOMIC DEVELOPMENT IN CENTRAL ASIA
}

\author{
Prof. Dr. Muhammad Ahmed Qadri \\ Former Dean \\ Faculty of Arts \& Social Sciences \\ University of Karachi \\ Karachi-Pakistan \\ prof.qadri@gmail.com \\ Sundus Qureshi \\ Research Scholar \\ Department of Political Science \\ University of Karachi \\ Karachi - Pakistan
}

\begin{abstract}
The New Silk Road (NSR), one of China's most ambitious economic plans, was unveiled by President Xi Jinping in 2013 and is intended to act as the Central Asian component of the Eurasian Belt and Road Initiative (Belt Road) (BRI). By enhancing and expanding China's security arc westward, as well as developing them as a transportation corridor connecting China to Europe, Beijing is able to consolidate its current economic investments while also launching new projects in Central Asia and South Asia, as well as attracting new investment from other countries. The NSR, touted by China as simply a development project, is loaded with wide-ranging security implications. China's infrastructure security and investment concerns in Central Asia are examined in this research, which examines the interplay between these two issues. China's non-state retaliation (NSR) in Central Asia is investigated in three ways: With its securitization push, the Silk Road Initiative not only consolidates the power of the Central Asian regimes; it also grants China an important position managing safeguards; and it allows the ultra-rich to move between the lure of Chinese investments and the appeasement of popular fears about China's growing influence. According to this report, NSR aid and investment from China has received an overall favourable reaction in the area, with some countries concerned about the consequences of the project on their
\end{abstract}




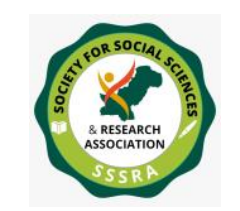

Pak. Journal of Int'L Affairs, Vol 4, Issue 3 (2021) New Silk Road: Implications of Economic ...

sovereignty and security, as well as the promise of connection and prosperity (a "win-win" situation). A look at China's growing security and economic commitment in Central Asia and the tight Sino-Russian friendship, as well as the areas of collaboration and complementarity between the two countries, is included in the article's concluding paragraphs.

Keywords: New Silk Road, China, Central Asia, Infrastructure, Sino-Russian Friendship.

\section{Introduction}

Xinjiang's restive area of Xinjiang is located in China's Central Asian region, which shares cultural and religious links with the restive province of Xinjiang as well as business and trade relations. Economic and political influence in Afghanistan and Central Asia has increased as a result of Xinjiang's industrial growth, Beijing's developing economic and commercial relations with Central Asia in the 1990s, and the founding of the Shanghai Cooperation Organization (SCO). It is part of Xi Jinping's BRI, which aims to connect China and Europe by expanding on Beijing's current investments and securitybuilding measures, while launching new projects to connect the areas of central and south Asia to China. A component of the BRI known as "yi dai yi lu," or the Maritime Silk Road, is the BRI (MSR). Silk Road Economic Belt, One Belt, One Road, and Belt and Road Initiative are all translations of this term in English that have been used by $\mathrm{Xi}$ in his speech in Astana (Xi 2013, Xi 2014, NDRC 2015). Following China's accession to the World Trade Organization in 2001, the BRI was touted as a vision of growth congruent with Chinese traditional culture, which places a premium on a peaceful and secure relationship with its neighbours. Xi Jinping envisions a militarily and economically strong China by the country's centenary, which he calls the "China Dream" and the "two centuries programmes" (Callahan 2016). The rapid rise of China has given China's leadership a "material" and "ideological" foundation upon which to advance its grand ideals of infrastructure connectivity on a global scale.

If China's actions have been "strategic regionalism" in Central Asia, as Kerr (2010) claims, according to Zhao (2007), the CCP strategy in the area has been far more ad hoc and lacking in strategic coherence compared to the policy in China. Under the NSR of the BRI, all of China's regional infrastructure projects and financial investments are brought together under a single roof. In 2013, NSR was launched. It is via a network of transport hubs strategically located on land and water that the BRI economic corridors connect these rail and road links, in line with Chinese objectives of economic and social progress and in strategically important locations for China's safety. There are far-reaching security 


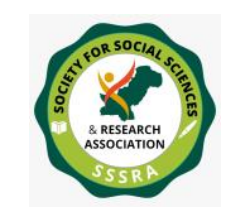

Pak. Journal of Int'L Affairs, Vol 4, Issue 3 (2021) New Silk Road: Implications of Economic ...

implications to the BRI/apparent NSR despite its seeming concentration on trade and infrastructure development.

This article examines China's investments in infrastructure and security dynamics as a crucial component of the Silk Road concept and the BRI. According to official statements and terminology, Central Asia is a cherished neighbour and an equal benefactor of the expansion, and China intends to widen its arc of security and transform it into a safe trade and transit corridor connecting it with Europe." A new phrase, "greater Central Asia," has been established following September 11, 2001, which includes the five post-Soviet governments of Kyrgyzstan, Kazakhstan; U.S.-administered Xinjiang, China; Afghanistan; and Pakistan's north and the territories bordering India as well as Xinjiang (Starr 2005; Clarke 2013). The BRI's Eurasian focus aligns nicely with this wide description of Central Asia's region. Russia's geostrategic thinking has recently advocated the concept of 'greater Eurasia,' which includes China, Afghanistan, the former Soviet territory, and friendly neighbouring areas such as India and Iran (SPIEF 2017). With China's backing, both the country and the SCO can officially use the term "Eurasian Union." We explore the reception of China's BRI/NSR in Central Asia in three ways using this broad definition: The securitization drive of the Silk Road Initiative supports Central Asian governments while also giving China a strong role in overseeing security arrangements.

China's aid and investment have been generally well received in the region, the implications of NSR for local sovereignty and security, however, have been a source of contention, and there have been some reservations about whether the advantages of connection and development (a "win-win" scenario) will truly materialise. All of this is mentioned in the article. As a result of its commitment not to intervene in domestic affairs and not to form military alliances, China is increasingly being pushed into security-related responsibilities, such as collaboration with national governments on counterterrorism measures, increasing border security, and assisting in the modernization of defence and military equipment, all of which are intended to protect Chinese projects and investments, as well as Chinese citizens.

\section{The New Silk Road}

Rather than being purely a Chinese effort, the New Silk Road has always been seen as a strategic idea to be fulfilled through "bilateral and multilateral cooperation mechanisms." White paper produced by Chinese Commerce Ministry, the Foreign Affairs Ministry and National Development and Reform Commission (NDRC), emphasises cooperation as a method for achieving strategic objectives. According to the document, 


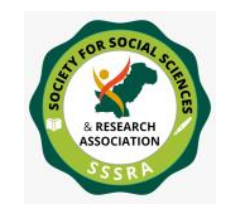

New Silk Road: Implications of Economic ...

"The Belt and Road Initiative is a methodical project, which should be cooperatively created via collaboration in order to suit the interests of all parties." According to the white paper, the New Silk Road initiative's strategic vision and objectives match with the responsibilities of various international organisations that Central Asian nations engage in. In the transportation sector, the CAREC is a crucial regional multilateral organisation that helps to achieve "road connectivity," a fundamental component of the New Silk Road. Before the establishment of the New Silk Road plan, CAREC was already engaged on cross-border transportation development in the larger Central Asian area, including China. There are six "flagship" transportation routes that are the focus of the CAREC's Transportation and Trade Facilitation Strategy. (Chikanaev 2017)

In Central Asia, a large number of ancient transportation channels are directed toward Russia, rather than China. Since 2001, CAREC has funded about $\$ 38$ billion to build these corridors, including $\$ 3$ billion in three that go to China. For example, the UrumqiKashgar route in CAREC Corridor 1 connects Xinjiang to Kazakhstan, Kyrgyzstan, and Russia. As part of the CAREC Corridor 2, Kazakhstan is connected to China, Russia, and western seaports, notably the Caspian Sea port of Aktau. Expedited toll expressways link Kazakhstan, Kyrgyzstan, Mongolia, Pakistan and Tajikistan via CAREC Corridor 5 in Xinjiang, China. Another important piece of regional infrastructure, the construction of energy pipelines, has mostly been accomplished through bilateral initiatives. It is important to note that China's Central Asia-China Gas Pipeline is the country's principal Central Asian pipeline project. Line A, Line B, and Line $\mathrm{C}$ have already been constructed, following the Turkmen-Uzbek border via Uzbekistan and Kazakhstan before arriving in Xinjiang, according to bilateral agreements with neighbouring countries. China secured bilateral agreements with Kyrgyzstan, Uzbekistan and Tajikistan in September 2013 to begin the construction of Line D. (ADB, 2015)

\section{New Silk Road's Impact on Central Asia}

"One prominent metaphor used to illustrate Xinjiang's intermediate placement between China, Central Asia, and beyond" is the Silk Road in discussions about the region (Millward 2009). It is in this context that the National Silk Road (NSR), which aims to connect China's Xinjiang region with the rest of Central Asia, differs from the mediaeval Silk Roads, which concentrated on Xinjiang as a central centre. Projects linking Xinjiang to Central and South Asia, including the Khorgos Free Economic Zone on China-border, Kazakhstan's are now part of the BRI/NSR and will be the world's largest "dry port" for Chinese goods, as well as CPEC, which connects Kashgar, Xinjiang, and Pakistan. NSR has been accepted by all five Central Asian countries and Russia, and they have tried to match their own socioeconomic and political goals with it. Every state in the region is 


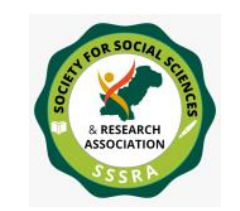

Pak. Journal of Int'L Affairs, Vol 4, Issue 3 (2021)

New Silk Road: Implications of Economic ...

excited about the possibilities of better transportation, trade and transit fees, as well as the development and export of its natural resources. They're all excited. Kazakstan, the ninthlargest state in the Eurasia, is essential to China's desire for land connectivity with Europe and increased market accessibility. Kazakhstan's geopolitical importance is complemented by its role as a major energy provider to China. China is responsible for at least $20 \%$ of the country's investment in oil production (Tengri News 2013).

To assist NSR and the Khorgos Free Economic Zone, Nazarbaev proposed a \$9 billion investment in Kazakhstan's railroad industry and other infrastructural developments. Nurly Zhol (Bright Path), a national plan, was reworked to emphasise the "complementarity" (sostykovka) between NSR and Nurly Zhol growth strategies, in the words of Russian politician "The Belt's Buckle" (pryazhka), Kazakhstan is Europe's "future economic growth" hinges largely on transportation infrastructure and regional trade," according to Kazakhstani analysts. Kazakhstan is the gateway to the Caspian Sea (Chikanaev 2017). China has previously invested heavily in Turkmenistan's and Uzbekistan's infrastructure projects, but the two countries have been more reluctant about opening up their economy to international investment (the Regional Anti-Terror Structure, RATS headquarters are located in Tashkent). With the Central Asia-China pipeline network, Turkmenistan has created a strong bilateral connection with China, despite its policy of "neutrality," which has permitted Turkmen gas to be transferred to China via Kyrgyzstan and Uzbekistan. As countries that are heavily reliant on Russian military and security aid, the development-oriented NSR and its promise of "win-win" outcomes appeal greatly to Tajikistan and Kyrgyzstan.

The Chinese National Petroleum Corporation and Central Asian counterparts such as Tajiktransgaz and Uzbekneftegas signed joint venture agreements to develop and operate Line D, which was completed in 2013. Central Asia-China pipeline Line D will be finished in 2016 with an annual capacity of 85 billion cubic metres, making it "the largest gas transmission system in Central Asia." There have also been significant collaborative ventures between China and Central Asian nations such as Turkmenistan's Amu Darya gas field development. The New Silk Road initiative's improved infrastructure, built via international and bilateral initiatives, is important to facilitating commerce. By 2017, 5 percent of all Europe-East Asia business is expected to be handled by transit countries, which would have a significant influence on their economies. By building oil pipelines through bilateral initiatives, trade is increased. The Turkmenistan-China gas pipeline, which would carry 55 billion cubic metres of gas annually, is estimated to increase China's annual natural gas consumption by $20 \%$ by the end of 2015 .

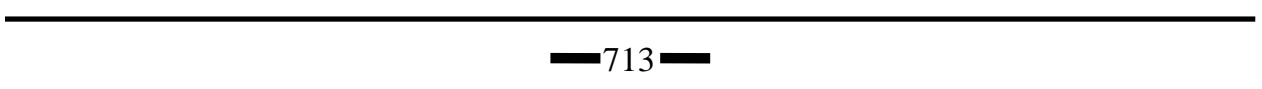




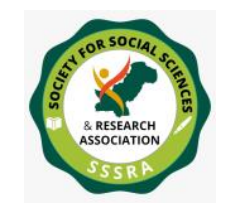

New Silk Road: Implications of Economic ...

Aside from infrastructural projects, China and Central Asian nations are working together to strengthen trade policies in the area. "Shuttle trade" between nations in Central Asia and China is a significant yet underappreciated type of informal commerce. Undocumented shipments of Chinese consumer goods pass through Kyrgyzstan and Kazakhstan on their way to the area, and the dealers who carry them profit from the arbitrage. Countries along the New Silk Road project will benefit from increased Chinese collaboration with Central Asian countries because of the New Silk Road program's focus on improving border management and reducing entrance barriers. Kyrgyzstan and Tajikistan have already inked cross-border transport agreements. Border crossing and transnational transportation of products can be enhanced through freight associations in Kyrgyzstan, which monitor travel times and wait periods.

New Silk Road initiative is likely to get increased attention from the Shanghai Cooperation Group (SCO), a regional security organisation. For commercial and financial cooperation, the SCO Interbank Consortium and the SCO Business Council include four Central Asian nations. This agreement was reached by both Chinese and Russian presidents at this year's summit of the Organization for Security and Co-operation in Europe (OSCE) in July. For the sake of regional economic growth, both nations called for a shared transportation system that combines and expands the amount of existing transportation networks like Russian Baikal-Amur and Trans-Siberian railways. Chinese economic participation in Central Asia will be facilitated by the SCO, which will help China achieve its New Silk Road aims.

\section{Chinese Financial Developments}

For decades, China has built a reputation as a low-cost, high-volume financier and builder of large-scale infrastructure development projects in Africa and other regions of the world, as well (Kobayashi and Sanchez 2017). Although the BRI's 65 member countries (as of October 2017) are aware that investing in unstable and unsafe regions is a risk, they have embraced the BRI (SIC 2017). In order to fill the "\$8 trillion infrastructural funding gap" that Western investors are reluctant to invest in Central Asian states that lack governance capacity and effective rule of law, China has been initiating new projects, providing financial and technical assistance, Kazakhstan is an exception. (ADB 2012). The Chinese economic model's credo of "stability and growth for everybody" (or "win-win") makes it an enticing option for local elites who lack other sources of capital. There are no long feasibility studies or environmental and sociopolitical considerations in China's ability to quickly disburse funds. When it comes to transportation and electricity, China has been filling in the gaps for Kyrgyzstan and Tajikistan. China has overtaken the United States as the world's leading foreign investor 


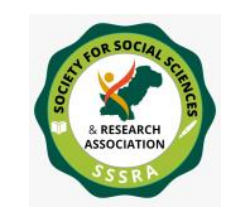

New Silk Road: Implications of Economic ...

in both, and as a result, it is taking on more responsibilities for security, which has the potential to have significant economic and political ramifications. China's investments in Kyrgyzstan have had a number of positive effects on the country's northern and southern regions, which are separated by mountains. President Almazbek Atambayev declared "energy independence" in 2015, after years of relying on Uzbekistan, with whom it has had a contentious relationship for years, after years of being dependent (Eurasianet 2015). Over the course of a year, direct energy links save Uzbekistan an estimated $\$ 8$ to $\$ 9$ million (Putz 2015).

The China-Kyrgyzstan-Uzbekistan railway project is one of the most ambitious and technologically demanding undertakings in western China and Kyrgyzstan, traversing high-altitude mountainous terrain. To get to Uzbekistan, China has proposed a route through Kyrgyzstan from Xinjiang. Chinese altruism has Kyrgyzstan doubtful, to put it mildly because of a historical disagreement with Uzbekistan and because a detour to get China's far northern areas on the proposed route would cost at least $\$ 1.5$ billion, which would raise doubts about China's altruism. With China's investments in Tajikistan, the Imomali Rahmon government aspires to convert the Central Asian state into a major transit route between China and the rest of the region. Besides hydroelectric power engineering, China has invested in Tajikistan's cement and manufacturing industries, cotton and vegetable farming, and other sectors. Over $\$ 1.1$ billion was invested into Tajikistan's economy during October 2016, making it the country's largest investor and knocking Russia out of the second spot. (Asia-Plus 2017)

China has invested heavily in medium-capacity hydroelectric power facilities, while Russia retains control of the larger hydroelectric power stations (Ferghana News 2017). An estimated $\$ 4$ billion is needed for improvements to the Rogun Hydropower Plant, which is the country's most critical strategic asset (BBC News 2013). China's investment and Russia's cooperation with China would be encouraged if the construction of the world's highest dam in Rogun begins in late 2018, according to Rahmon's announcement in late 2018. It may appear at first glance that China's financing of infrastructure projects in the Central Asian area is advantageous to everyone. Responded to the "win-win" situation, Central Asian leaders reaffirmed their nations' and people's bonds, expanded strategic collaboration, and anticipation of mutual advantages. To avoid delays or obstructions in the execution of initiatives, funding and aid can be supplied fast without public discussion or involvement of non-state actors.

As a result of the influx of Chinese investments, which were made without consideration of a repayment plan or the ability of the recipient countries to absorb help, Kyrgyzstan and Tajikistan's foreign debts have skyrocketed. However, the $\$ 600$ million that 


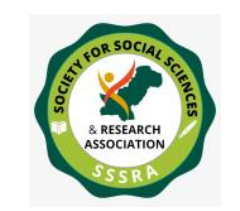

Pak. Journal of Int'L Affairs, Vol 4, Issue 3 (2021)

New Silk Road: Implications of Economic ...

Tajikistan received was not clear on whether it was a loan from the Organization for Security and Co-operation in Europe ( $\mathrm{SCO}$ ) or a loan from one of its member nations. Over half of Tajikistan's foreign debt is owed to China, at $\$ 2.3$ billion (Chorshanbiyev 2017). Almost $40 \%$ of Kyrgyzstan's $\$ 3.76$ billion in foreign public debt is owed to China's Exim Bank, which owes $\$ 1.4$ billion to the country (Business World 2016). There is also the issue that while some of China's major projects have been proven feasible, China's commitment to finishing projects that look less profitable to Beijing but potentially have a significant impact on the Central Asian republics involved has been questioned indefinitely. Line D, which would have allowed Kyrgyzstan and Tajikistan to gain millions of dollars a year in transit fees, has been indefinitely postponed due to several delays. ' China's economic slowdown may be attributed to lower global energy costs, China's present energy surplus, and China's lower growth rates, according to some. That's what Lelyveld (2017) said.

\section{Chinese Strategy for a "Win-Win" Scenario}

As China has expanded its economic and geopolitical influence in Central Asia, the Russian government's response to this has been largely muted. Since Russia relies heavily on China's domestic energy market, the two countries have created a "win-win" arrangement. Russia produced 12.9 percent of the world's oil in 2013, according to British Petroleum data. As for the rest of the globe, China accounted for $12.5 \%$ of global oil consumption. Since China is both the world's largest energy consumer and a fastdeveloping emerging nation, it looks to have no problem negotiating energy contracts with Central Asia and Russia. Jane Nakano and Edward C. Chow of the Center for Strategic and International Studies feel that China and Russia may benefit from each other in the energy market. In order to meet domestic demand and protect the environment, Russia's natural gas exports must be more diverse, and China must buy more energy. More than 70 percent of Russia's total export profits come from oil and gas, notwithstanding the country's economic turmoil and dropping oil prices. From this combination of complementary objectives came several multi-lateral agreements in 2014. It was in May of this year that China and Russia struck a $\$ 400$ billion natural gas supply agreement. First deliveries of 38 billion cubic metres of natural gas per year from West Siberia will begin in 2018 after China and Gazprom agreed to a contract. (Scobell, Ratner, and Beckley, 2014)

A minimum of 3 million tonnes of LNG and a twofold increase in Russia's oil supply to China will be provided by Novatek and Rosneft, respectively. There are two "strange developments" in Russia's energy sector, according to the Russian government: Novatek has a $20 \%$ stake in its project, and Rosneft has a $49 \%$ stake in its East Siberian oil 


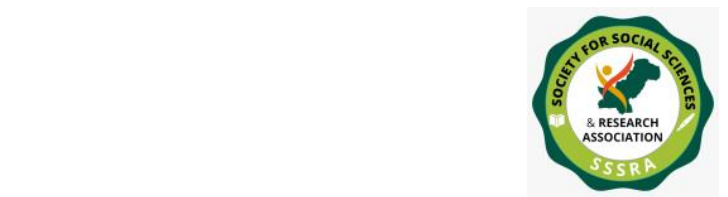

Pak. Journal of Int'L Affairs, Vol 4, Issue 3 (2021)

New Silk Road: Implications of Economic ...

development project. Russia's best interests are served by increasing its energy exports to Asia while Europe's markets remain stagnant and the European Union has placed economic sanctions on Russia. Russia's energy policy through 2035, announced in 2014, said that by 2035, "23 percent" of Russia's oil and gas exports will be sent to the AsiaPacific region, compared to the current 6 percent. China, on the other hand, dwarfs Central Asian countries in terms of size, reputation, economic force, and political heft. With China's economic relations, these countries face challenges and opportunities alike. Although China has a long-term goal of improving the region's infrastructure, Chinese imports from Central Asia are mostly raw materials, and Chinese infrastructure projects usually employ more Chinese than locals. However, China is also a major exporter of apparel, home appliances and electronics to Kazakhstan. (FMPRC, 2015)

Public dissatisfaction and social friction might arise as a result of the disparity in trade quantities and content between Central Asian nations and China, as evidenced by the protests in Almaty, Kazakhstan, in 2010. As important as it is to acknowledge and address these concerns, they should not obscure the reality that China and Central Asian countries have "win-win" economic prospects that may benefit both countries. The New Silk Road can help Central Asian countries diversify their trading partners and reclaim their place in "trans-continental transit commerce," as commodities are transported "along the reemerging East-West and North-South trade routes." The New Silk Road programme is a "win-win" for both Central Asia and China since it expands and diversifies trade prospects. Transit fees collected from countries along the CAREC Corridor 1 will be a substantial source of revenue for the nations it passes through, including Europe, Kazakhstan, China and Russia. As part of CAREC Corridor 5, the KorlaKuqa highway links "improved rural roads to schools, hospitals and marketplaces for around 50,000 rural residents," allowing for the increase of commerce and enabling economic growth. Oil and gas are China's most important export to Central Asia, and the countries of Central Asia are just as interested in diversifying their energy exports as China is in purchasing them. In 1998, Prime Minister Viktor Chernomyrdin halted the export of Turkmenistan gas to remind Russia of the significance of commercial diversification. Uzbekistan and Turkmenistan, two Central Asian nations with more politically autonomous ties to Russia, have seen an increase in trade ties with China. Uzbekistan, for example, relies on China for 60 percent of its energy needs. (Fedorenko, 2019)

\section{Conclusion}

This article examines the Central Asian republics' responses to Chinese investments. Western media have been sceptical about the NSR despite the positive reception it has 


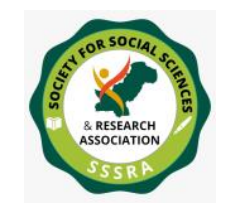

New Silk Road: Implications of Economic ...

received in Russia and Central Asia (Le Corre 2017, DW 2017). A multilateral link between BRI and the EEU (Armenia, Belarus, Kazakhstan and Kyrgyzstan) has been pushed by Putin since he signed a BRI/NSR Agreement with Xi Jinping in May 2015 that aligns both BRI and EEU goals. Chinese President Xi Jinping's statements, such as: "We do not want to manage regional affairs or construct any sphere of influence," After Russia and the Central Asian countries committed to work together to build a "region of harmony," people's trust in the leadership of both countries has strengthened (Xi 2013). Although China's foreign policy and peaceful development commitments were addressed to its Silk Road neighbours, not Europe, Xi's words were not directed at Europe. As a result of German and French business lobby demands, Europe's sluggish responses to NSR, and a hesitant reception (EP 2016, Interviews, Brussels, Berlin 2017). A lack of leadership from the US in the area has left the EU and European institutions with a difficult task: keeping their niche and a cohesive policy in the region, while strengthening their strategic engagement with China and forging a cooperation pact between the NSR and EEU. China's "16+1" BRI strategy, which overlooks EU and non-EU borders, is worsened by the BRI promise of growth and investment in Central Asia, but it is also exacerbating tensions in Europe. Chinese investors are growing interested in transport and energy infrastructure projects in EU candidate nations in Southeast Europe, notably cash-strapped Greece (Piraeus) and Hungary (Belgrade-Budapest Railway). China's investments through the BRI are further weakening the EU's consensus-based approach in light of Greece's opposition to the EU statement on China's Human Rights in July 2017. China's financial and cultural institutions are behind the BRI, as we have emphasised in the past. According to a European Union report, this has led to the view in the EU of "[placing] the China mark on the globe" and "imposing a true global system but not like ours, based on human rights and individual liberties" (German Foreign Minister Sigmar Gabriel cited in Erlanger 2018). European Union policymakers in Central Asia have the problem of establishing a strategic coherence in order to sustain their role as an authoritative normative authority in the area in the face of Xi Jinping's decade-long presidency. The NSR's different reactions in Central Asian nations, ChinaCentral Asia participation in the NSR, and strong Sino-Russian bilateral cooperation, including NSR and EEU cooperation, all have significant and far-reaching consequences for Europe. The EU's approach to China and the Eurasian region must be rethought in order to strengthen its own normative security building vision in the region through bilateral and multilateral involvement.

In light of the AIIB's rise as the region's largest investor, there are encouraging indicators that new pathways of economic engagement between China and Europe are emerging as the AIIB gives a new direction to projects usually sponsored by the ADB. If you're looking for an example, AIIB and EBRD are working together on the Dushanbe- 


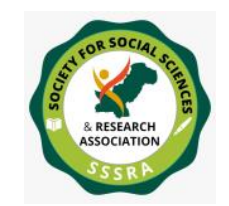

Uzbekistan Road development project, which includes a \$105.9 million initiative to repair a five-kilometer stretch between these two cities (AIIB 2016). The AIIB has joined the EBRD and ADB in sponsoring phase two of the Tajik Road project, which was originally funded by the two organisations (EBRD 2012). (EBRD 2016 [b]). Even while an economic collaboration between China and Europe is taking shape in the area, the characteristics of Chinese finance discussed above warn us that this cooperation is based on common aims rather than shared ideals, even if it promotes values that are diametrically opposed. The EU has to adopt its own policy in light of China's increasing economic and political involvement in Central Asia. A cooperation with the AIIB to create infrastructure and augment them with the EU's technical competence, as well as measures to enhance governance and capacity for aid in which EU institutions have aided significant development programmes, are some of the initiatives. However, despite the disparities in ideology and normative purpose, there are areas of collaboration and complementarity that may be recognised. It is possible to boost China's capacity to construct hard transport and commerce infrastructure by using Europe's reputation for long-term durability and stability in scientific-intellectual training, soft infrastructure and service supply. 


\section{References}

AIIB (2016) Asia for the Future, Annual Report and Accounts 2016. AIIB. https://www.aiib.org/en/newsevents/news/2016/annualreport/.content/download/Annual_Report_2016.pdf.

Asia Development Bank [ADB] (2012) Public Private Partnerships Key to Meeting Asia's \$8 Trillion Infrastructure Needs - Study. ADB.

http://www.adb.org/news/public-privatepartnerships-key-meeting-asias-8-trillioninfrastructure-needs-study.

Asian Development Bank. (2015) "The New Silk Road: Ten Years of the Central Asia Economic Cooperation Program." http://www.adb.org/sites/default/files/publication/29389/new-silk-road.pdf.

Asia-Plus(2017) China leads in direct investment in Tajikistan's economy. Asia-Plus. https://www.news.tj/en/news/tajikistan/economic/20170203/236278.

BBC (2013) Tajikistan's Rogun: Building the world's tallest dam. BBC News. http://www.bbc.com/news/world-asia-37929367.

Business World (2016) Kyrgyzstan: Debts to China the worst. Business World. https://smiraponitke.com/02/12/2016/kyrgyzstan-debts-to-china-the-worst.html.

Callahan W A (2016) China 2035: from the China Dream to the World Dream, Global Affairs, 2:3, 247-258.

Chikanaev S (2017) Kazakhstan: 'pryzhka' Poyasa- puti (kontseptsiia Odin poyas - Odin Put) [Kazakhstan: 'Buckle' in Belt and Road (The Concept of One Belt- One Road)]. GRATA International.

Chorshanbiyev P (2017) Tajikistan's foreign debt nears 2.3 billion U.S. dollars. AsiaPlus. https://www.news.tj/en/news/tajikistan/economic/20170524/240186

Clarke, M (2013) China's Strategy in "Greater Central Asia: Is Afghanistan the Missing Link? Asian Affairs: An American Review 20:1, 1-19.

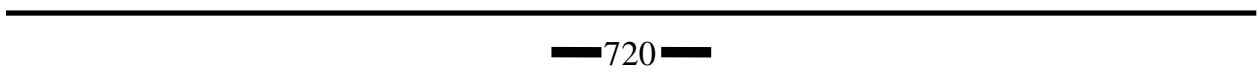


New Silk Road: Implications of Economic ...

DW (2017) 'New Silk Road and China's hegemonic ambitions. DW. http://www.dw.com/en/new-silk-road-and-chinas-hegemonic-ambitions/a$\underline{38843212 .}$.

EBRD (2012) Key link in the road from Tajikistan to the world. http://www.ebrd.com/news/2012/key-link-in-the-road-from-tajikistan-to-theworld.html.

EBRD (2016 [b]) Road safety for key thoroughfare of Dushanbe, Tajikistan. http://www.ebrd.com/news/2016/road-safety-for-key-thoroughfare-ofdushanbetajikistan.html.

EP (2016) Briefing: One Belt One Road - China's Regional Integration Initiative. http://www.europarl.europa.eu/thinktank/en/document.html?reference=EPRS_BR I(2016)586 608

Eurasianet (2015) Kyrgyzstan Hails Epoch-Making Power Line. Eurasianet. https://eurasianet.org/node/74876

Fedorenko, V. (2019) "The New Silk Road Initiative in Central Asia," Rethink Institute, Working paper 10. http://www.rethinkinstitute.org/wpcontent/uploads/2013/11/Fedorenko-The-New-Silk-Road.pdf.

FMPRC. (2015) "President Xi Jinping Delivers Important Speech and Proposes to Build a Silk Road Economic Belt with Central Asian Countries." http://www.fmprc.gov.cn/mfa_eng/topics_665678/xjpfwzysiesgjtfhsh zzfh_665686/t1076334.shtml.

Kerr D (2010) Strategic Regionalism: Central Asian and Russian Perspectives on China's Reemergence. International Affairs. 86,1:127-152. Doi: 10.1111/j14682346.2010.00872.x

Kobayashi Y and Sanchez A (2017) Minilateralism à la Chine. Lau China Institute Policy Paper Series. 1, 6:2-17. https://www.kcl.ac.uk/sspp/departments/lci/documents/policypapers/KobayashiSanchez-Final-policy-brief-17-August-2017.pdf.

Le Corre P (2017) Europe's mixed views on China's One Belt, One Road initiative. Brookings. https://www.brookings.edu/blog/order-fromchaos/2017/05/23/europes-mixedviews-on-chinas-one-belt-one-road-initiative/. 
Lelyveld M (2017) China Shelves Central Asia Gas Plan. Radio Free Asia. http://www.rfa.org/english/commentaries/energy_watch/china-shelves-centralasia-gas-plan03202017103720.html

Millward J (2009) Positioning Xinjiang in Eurasian and Chinese History: Differing Visions of the 'Silk Road'. In Clarke M and Mackerras C (eds). China, Xinjiang and Central Asia: History, Transition and Future Prospects into the 21st Century. Routledge, London, 55-74

National Development and Reform Commission [NDRC] (2015) Vision and Actions on Jointly Building Silk Road Economic Belt and 21st-Century Maritime Silk Road.

National Development and Reform Commission. http://en.ndrc.gov.cn/newsrelease/201503/t20150330_669367.html

Putz C (2015) Kyrgyzstan Declares Energy Independence. The Diplomat. https://thediplomat.com/2015/09/kyrgyzstan-declares-energy-independence/.

Scobell, A. Ratner, E. and Beckley, M. (2014) "China's Strategy Toward South and Central Asia: An Empty Fortress." Rand Corporation. http://www.rand.org/content/dam/rand/pubs/research_reports/RR500 /RR525/RAND_RR525.pdf.

SPIEF [St Petersburg International Economic Forum] 2017: From Wider Europe to a Big Eurasian Partnership? (2017) Eurasian Studies: Higher School of Economics, Russia. http://greater-europe.org/archives/2955.

Starr, S F (2005) A ‘Greater Central Asia Partnership' for Afghanistan and Its Neighbors. Central Asia-Caucasus Institute \& Silk Road Studies Programme, Johns Hopkins University.

State Information Council [SIC] (2017) Big Data Report of Trade Cooperation Under the Belt and Road Initiative. State Information Council. https://www.yidaiyilu.gov.cn/wcm.files/upload/CMSydylgw/201703/2017032412 43039.pdf.

Tengri News (2013) Share of China's companies in Kazakhstan's oil production estimated at 24\%. Tengri News. https://en.tengrinews.kz/markets/Share-ofChinas-companies-inKazakhstans-oil-production-24323/ 
Xi J (2013) Promote Friendship Between Our People and Work Together to Build a Bright Future. Ministry of Foreign Affairs.

http://www.fmprc.gov.cn/mfa_eng/wjdt_665385/zyjh_665391/t1078088.shtml.

Xi J (2014) The Governance of China. Foreign Languages Press, Beijing

Zhao H (2007) Central Asia in China's Diplomacy. In Rummer E, et. Al (ed). Central

Asia: Views from Washington, Moscow and Beijing. ME Sharpe, Armonk New

York, 137-214 